\title{
The Sizzling of Desire
}

\section{A Psychoanalytic Study of Clyde's Character in An American Tragedy}

\section{Karzan Kawsin Babakir}

Department of English Language, University College of Goizha, Sulaimaniyah, Kurdistan Region, Iraq.

E-mail: karzan.babakir@uog.edu.iq

\begin{abstract}
:
An American Tragedy is a novel by Theodore Dreiser. It was published in 1925. The novel is a complicated account of an ambitious, ill-educated, and immature young protagonist named Clyde Griffith. It is a portrayal of the society whose values both shape Clyde's mimetic desires and seal his destiny. Since the novel revolves around the strong desires of Clyde and the way they reflect on him and others around him, this paper offers an analysis of the character through the lens of psychoanalysis. This study is an attempt to shed light on the deep-rooted desires of the protagonist and how they affect him for his assumed success in life. In this regard, the beliefs of Sigmund Freud and some other writers in the field are discussed.
\end{abstract}

Keywords: Clyde Griffith, Desire, Mimesis, Theodore Dreiser, Psychoanalysis. 


\section{1-Introduction:}

Clyde Griffiths is the protagonist in Theodor Dreiser's An American Tragedy. He lusts after wealth and pleasure. He is chasing after material wealth in order to buy expensive clothes, be driven around in attractive cars, dine in luxurious restaurants and be with beautiful girls. At the beginning of the novel, the character of Clyde is introduced with the characteristics of rebellion against the parental dominance, and the traditional rule of the society.

Clyde is an impatient young man who resents his parents' religious work in the mission house and on the city streets. When he was in a gathering of religious mission, he contemplated about his disorientation:

During all this time Clyde was saying to himself that he did not wish to do this anymore, that he and his parents looked foolish and less than normal_ "cheap" was the word he would have used if he could have brought himself to express his full measure of resentment at being compelled to participate in this way-and that he would not do it any more if he could help (Dreiser, 2002, P.19).

Dreiser starts to show the protagonist of his novel as a type of character who thinks differently and would like to do what is different. Clyde can be regarded as the type of character who shifts from tradition-directed type, due to his intention to adapt to recent cultural trends. He "becomes an example of the other-directed character-type, taking his cues from others and using his contemporaries as models on which to base his own personality" (Spindler 66). Thus, Clyde becomes more open to the direct social setting than to the reverberations of the past parental orders in his head. As a result, his attitudes and desires, the new world and acquaintances conspire to meet his doom.

\section{2-Desire for What is Beyond:}

There are scenes that Clyde has not found in his immediate surroundings and towards which he shows his great amazement. For example, the scene of Green-Davidson hotel and its lobby are more arresting, since the timorous poverty has restrained him from exploring such a world (Dreiser, 2002, p. 48). Or when he first sees Sondra Finchley, who to Clyde's eyes was the most adorable feminine thing he has seen in his lifetime (Ibid, p. 325). All this bewilderment makes Clyde more curious about the other side of his environ in which he later attempts to fit. Psychologically, his primitive part of personality prevails over his rationality, or in Freudian terms, the id overcomes Clyde in his will and behavior. This side of Clyde's personality is obvious when the more he sees, the more he wants (Lehan, 1963, p. 187 ). The desire and greed and the need for their fulfilment are considered as part of human nature. This is further analyzed in the concept of id theorized by the Austrian psychoanalyst Sigmund Freud (1856-1939). According to Freud, the id is the part of the personality that embraces human beings' basic desires like thirst, anger, hunger and the desire for immediate fulfillment or release. Furthermore, the id is innate in human beings. It is a vital part of personality since infancy and it allows for the primitive needs to be fulfilled. He also believes that the id is based on the human desire principle. The id wants whatever feels decent at a time, regardless of concern for the other states of the situation (Niaz, Azadkhan et al., 2019, P. 38). Hence, the unfulfilled desires never give up Clyde and are continuously echoed in his mind. 


\section{3-The Desire and the Choice:}

Clyde's desires push him in an obvious way when he is about to make an ultimate choice between two women, Roberta Alden, a pretty factory girl and Sondra Finchley, a rich socialite: "Pah—how cowardly-how lacking in courage to win the thing that above all things you desire - beauty - wealth - position - the solution of your every material and spiritual desire" (Dreiser, 2002, p. 686). This is the way in which Clyde needs courage to solve his unsatisfied desire. He apparently ridicules himself in order to enhance his will towards action. To him "the thing that above all things you desire" should settle the hesitation he is caught in.

Clyde crosses the boundaries of love, for he mixes up the humans with materials and status. Thus, what is important is what he desires not who he loves; choosing to love is the way through prosperity and wealth. In this respect, Freud knowingly has said, "Where they love they do not desire and where they desire they cannot love" (Ibid, P. 251). This is the reason why there is a case of unrequited love. At the beginning there is "the ungoverned and carnal desires!" of Clyde for a working girl, since he abandons her after making her pregnant and even manages to get rid of her (Dreiser, 2002, p. 862). Meanwhile, there is a "desire to marry a rich girl” (Ibid, p. 839). The qualifier of "rich" determines the desire, for desire could also concern longing and possessing. As Stampe says, "There is the very fact that one wants the thing-the desire itself; or the fact that one doesn't have it" (Ibid, p. 338). Accordingly, the poor Clyde desires someone rich before he desires a girl as a potential partner.

\section{4-The Mimesis of the Desire:}

Overall, Clyde's desire was not an ordinary one, but rather memetic. In Clyde's case, the matter is "how he looked and how other boys looked" and how they appeared and what they had (Ibid, pp. 28-29). He yearns for what he did not have and found it essential to adapt with others around. He was becoming increasingly impatient, as "All troubled Clyde with a sense of something different, better, more beautiful than his, or rather their life" (Ibid, p. 16). According to Burgis, When mimesis prevails, people develop an obsession with vanquishing some Other, and measure themselves according to them. When an individual's identity becomes completely attached to a mimetic model, they can never truly evade that model, since doing so would mean destroying their own reason for being (2021, p. 12). Accordingly, the reason for being is not just desiring to be like the other, but rather becoming the other in what they are and what they have.

For Clyde, the mentality of "Us versus Them" is at work in terms of socio-economic status. He longs for likeness in everything and that is making him fall in deep thought most of the time. Doyle, a bellboy whom Clyde has perceived as being the embodiment of Chesterfieldian style and looks, becomes a model in the youth's crowd for Clyde to imitate. However, when he joins the crowd, it is not easy to exit (Dreiser, 2002, pp. 83, 84). After all, it is what he has wished for; to become like them in everything and break up from his wretchedness. He also needs to learn what they already know in order to fulfill his desires (Farrell, 1976, p. 21). Consequently, his differences with the crowd vanish and the feeling of equality emerges. This is the time when "all who belong to the crowd get rid of their differences and feel equal. These differences are mainly imposed from outside; they are distinctions of rank, status and property" (Canetti, 1962, p 17). Clyde shortens his distances of his with the crowd, since as long as he closes himself in his house and space, he can never annihilate the social distinctions. Once joins the crowd, he is safe, although at the beginning he is not when judging himself against others and accepting himself through their evaluations. This could be considered as a characteristic of American ambition which is not only about achieving comfort but rather the accumulation of wealth involving power and social dominance 630 
(Dreiser, 1977, p. 26). As a result, the imitation of others within a group gives Clyde an advantage to not only become like them but also have expectations of what he considers as success in life.

\section{5-The Unconscious Working of Desire:}

Clyde's disdain for the homeless who regularly visits his parents' mission grows as he learns to look down on the speaking and behavior of the bellboys he works with. He intends to make sure that he breaks free from his old self and embodies his new self in the new group. Even though part of his self is always fighting to get approval in a group, another part finds endorsement only by excluding others. This becomes a two-sided battle, the result of which could be an apparent success, a desired one, though (Eby, 1993, p. 203). As far as he stays within the group and identifies with others around him, the feeling of triumph also lingers.

Given the values which prevails in the society, Clyde is "quite right that with the addition of money, clothes, and a car — all "in the Gilbert Griffiths fashion"— he would be "as attractive" to the most desirable of girls as Gilbert - in effect, equal or tantamount to him" (Orlov, 1977, p. 462). Clyde considers his rich cousin as an example of magnetic personality to whom everything, including beautiful girls are attracted. In one of his fantasies about his possible relationship with Sondra, she mistakes him for his cousin Gilbert:

Ah, to know this perfect girl more intimately! To be looked upon by her with favor,- made, by reason of that favor, a part of that fine world to which she belonged. Was he not a Griffiths - as good looking as Gilbert Griffiths any day? And as attractive if he only had as much money —or a part of it even. To be able to dress in the Gilbert Griffiths' fashion; to ride around in one of the handsome cars he sported! Then, you bet, a girl like this would be delighted to notice him,- - mayhap, who knows, even fall in love with him (Dreiser, 2002, pp. 457, 458).

This burning desire for the wealth by which a beautiful and rich girl could be owned implies that Clyde is sure about the power of wealth and what it can do. He puts himself in the place of his rich and attractive cousin with whom a girl like Sondra could fall in love. Hence, to him all that matters is material possession and the feeling it might give due to its supposed influence on others. In this regard, Freud once again stresses on the weight of unconscious mind which id represents.

Freud thought that not only was much of the human beings' mental life unconscious but that the repressed part of the unconscious mind functions based on a different principle than the reality principle that ruled the conscious ego. This type of unconscious thinking is wishful and it merrily ignores the logic and the arrow of time (Solms, 2004, p. 86). Clyde not only has a wishful thinking most of the time, but due to this repressed part of the unconscious, he plots to cause an "accidental" drowning of Roberta. This happens when her boat capsizes accidentally, but Clyde does not answer Roberta's call for help (Dreiser, 2002, pp. 684-725). This was how the hidden wishes and desires of Clyde reflects on his passive behavior towards a sinking human being. The desires he has are deeply rooted in his unconscious, something which prevents him from acting like a moral and rational person. 


\section{Conclusion:}

In Dreiser's An American Tragedy, desire is an important factor that prevails upon Clyde Griffith's personality and rules his behavior. Clyde is a deprived individual from a religious and impractical family, something which he despises and wants to escape from. When he is acquainted with the other side of the his world, he becomes bewildered and increasingly more curious about it. Becoming familiar with a new environment and a group of youth, makes him over-ambitious and causes him to cross the approved social boundaries. Psychologically, the unconscious mind prevails upon his attitudes and behavior; as a result, the desires lead him astray and seal his fate. Clyde's burning desires became clearer when reflected on his passive behavior towards a sinking human being. 


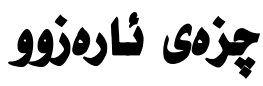

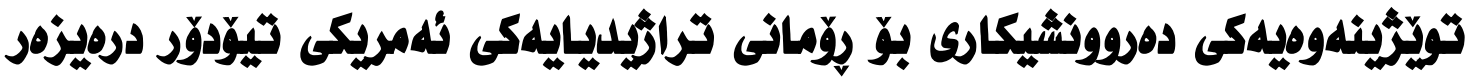

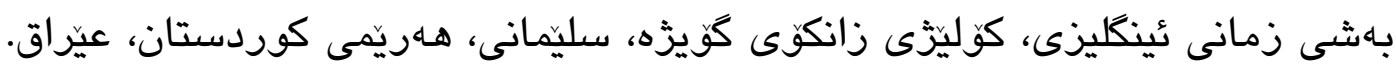

كارزان كاوسين بابكر

karzan.babakir@uog.edu.iq كيمهيل:

هوخته:

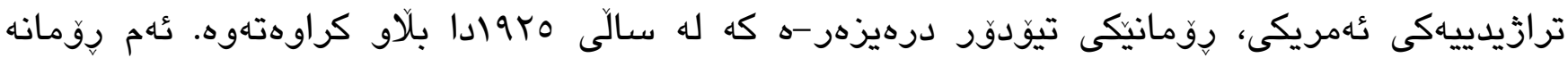

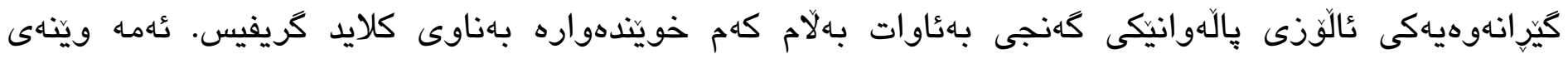

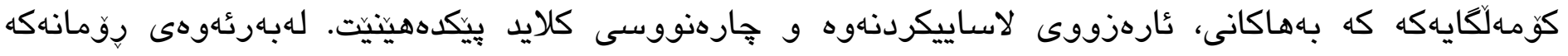

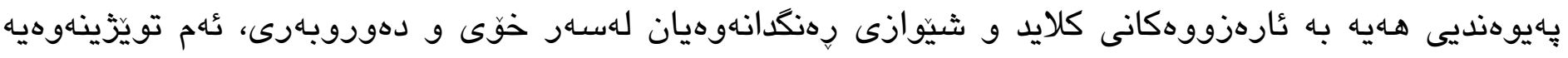

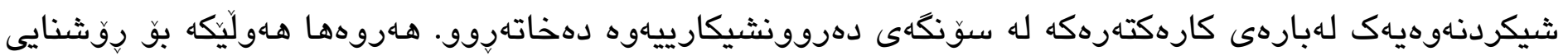

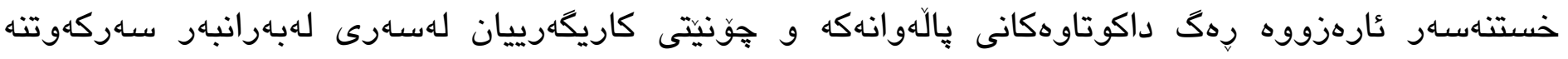

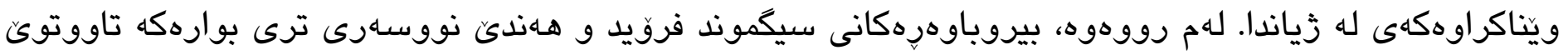
دهكرين.

كيله وشُهكان: كلايد كَيفيس، عارهزوو، لاساييكردنهوه، تيوّور درهيزهر، دهروونثيكارى. 


\section{References:}

Burgis, L., (2021)., Wanting. The Power of Mimetic Desire .London: Swift Press.

CANETTI, E., \& STEWART, C. (1962). Crowds and power

Dreiser, Theodor., (2002). An American Tragedy. Rosetta Books, LLC.

Eby, C., (1993)., The Psychology of Desire: Veblen's "Pecuniary Emulation" and "Invidious Comparison" in Sister Carrie and An American Tragedy. Studies in American Fiction, 21(2), pp.192-208.

Farrell, J., (1976)., Dreiser's Tragedy: The Distortion of American Values. Prospects, 1, pp.19-27.

Richards, Angela., (ed.). (1977)., On the Universal Tendency to Debasement in the Sphere of Love. On Sexuality. Penguin Books, 1977, pp. 243-60.

Lehan, Richard., 1963. Dreiser's An American Tragedy: A Critical Study. College English, 25(3), pp. 187-93, https://doi.org/10.2307/373686.

Niaz, A., Stanikzai, S. and Sahibzada, J., 2019. Review of Freud's Psychoanalysis Approach to Literary Studies. American International Journal of Social Science Research, 4(2), pp.35-44.

Orlov, Paul A. (1977),, THE SUBVERSION OF THE SELF: ANTI-NATURALISTIC CRUX IN ‘AN AMERICANTRAGEDY. Modern Fiction Studies, 23(3), pp. 457-472.

https://www.jstor.org/stable/pdf/26280277.pdf?refreqid=excelsior\%3A861ecfdf8c2410463e27d15c632c1e02.

Pizer, Donald (ed.). (1977). I Find the Real American Tragedy. Theodore Dreiser: A Selection of Uncollected Prose, Wayne Statue University Press.

Solms, M., (2004). Freud Returns. Scientific American, 290(5), pp.82-88.

Spindler, M., (1978). Youth, Class, and Consumerism in Dreiser's An American Tragedy. Journal of American Studies, 12(1), pp.63-79.

Stampe, D., (1987)., The Authority of Desire. The Philosophical Review, 96(3), p.335. 